DOI $10.31489 / 2021 \mathrm{M} 2 / 5-15$

MSC 35N25, 65J22, 39A14

\author{
A. Ashyralyev ${ }^{1-3}$, A.S. Erdogan ${ }^{4, *}$ \\ ${ }^{1}$ Near East University, Nicosia, Turkey; \\ ${ }^{2}$ Peoples' Friendship University of Russia (RUDN University), Moscow, Russia; \\ ${ }^{3}$ Institute of Mathematics and Mathematical Modeling, Almaty, Kazakhstan; \\ ${ }^{4}$ Palm Beach State College, FL, USA \\ (E-mail: allaberen.ashyralyev@neu.edu.tr, aserdogan@gmail.com)
}

\title{
Parabolic time dependent source identification problem with involution and Neumann condition
}

\begin{abstract}
A time dependent source identification problem for parabolic equation with involution and Neumann condition is studied. The well-posedness theorem on the differential equation of the source identification parabolic problem is established. The stable difference scheme for the approximate solution of this problem and its stability estimates are presented. Numerical results are given.
\end{abstract}

Keywords: well-posedness, coercive stability, source identification, exact estimates, boundary value problem.

\section{Introduction}

The theory and applications of source identification problems (SIPs) for partial differential equations have been studied and for references we refer to articles [1-9] and the references given therein. Also, numerous source identification problems for hyperbolic-parabolic equations and their applications have been investigated too (see, e.g., $[10-13]$ and the references given therein). In the last decade partial differential equations with involutions were investigated by several authors including Ashyralyev and Sarsenbi [14-17]. However, source identification problems for parabolic equations with involution still need more investigating.

The present paper is devoted to the study of a time SIP for parabolic equation with involution and Neumann condition. The stability theorem on the differential equation of the source identification parabolic problem is proved. The stable difference scheme (DS) for the approximate solution of this problem is constructed. Furthermore, stability estimates for the DS of the time source identification parabolic problem are established. Numerical results are provided.

\section{Stability and coercive stability of the differential problem}

We consider the time SIP

$$
\left\{\begin{array}{l}
u_{t}(t, x)-\left(a(x) u_{x}(t, x)\right)_{x}-\beta\left(a(-x) u_{x}(t,-x)\right)_{x}+\delta u(t, x) \\
=p(t) q(x)+g(t, x),-l<x<l, 0<t<T, \\
u(0, x)=\varphi(x),-l \leq x \leq l, \\
u_{x}(t,-l)=u_{x}(t, l)=0, \int_{0}^{l} u(t, x) d x=\gamma(t), 0 \leq t \leq T
\end{array}\right.
$$

for the one dimensional parabolic differential equation with involution and Neumann boundary condition. Throughout this paper, we assume that the following conditions hold

$$
\begin{gathered}
\bar{a} \geq a(x)=a(-x) \geq \underline{a}>0, x \in(-\ell, \ell), \underline{a}-\bar{a}|\beta| \geq 0, \delta \geq 0, \\
q^{\prime}(-l)=q^{\prime}(l)=0, \int_{0}^{l} q(x) d x \neq 0 .
\end{gathered}
$$

Under compatibility conditions, identification problem (1) has a unique solution $(u(t, x), p(t))$ for the smooth functions $g(t, x),(t, x) \in(0, T) \times(-l, l), a(x), q(x), x \in(-l, l)$ and $\gamma(t), t \in[0, T], \varphi(x), x \in[-l, l]$.

\footnotetext{
${ }^{*}$ Corresponding author.

E-mail: aserdogan@gmail.com
} 
Assume that $H$ is a Hilbert space and $A$ is the self-adjoint positive-definite operator defined by the formula

$$
A z=-\frac{d}{d x}\left(a(x) \frac{d z(x)}{d x}\right)-\beta \frac{d}{d x}\left(a(-x) \frac{d z(-x)}{d x}\right)+\delta z(x)
$$

with domain

$$
D(A)=\left\{z: z, z^{\prime \prime} \in L_{2}[-l, l], z^{\prime}(-l)=z^{\prime}(l)=0\right\} .
$$

Here and in the rest of this paper, $C_{0}^{\alpha}([0, T], H)(0<\alpha<1)$ stands for Banach spaces of all abstract continuous functions $\varphi(t)$ defined on $[0, T]$ with values in $H$ satisfying a Hölder condition with weight $t^{\alpha}$ for which the following norm is finite

$$
\|\varphi\|_{C_{0}^{\alpha}([0, T], H)}=\|\varphi\|_{C([0, T], H)}+\sup _{0 \leq t<t+\tau \leq T} \frac{(t+\tau)^{\alpha}\|\varphi(t+\tau)-\varphi(t)\|_{H}}{\tau^{\alpha}} .
$$

Here, $C([0, T], H)$ stands for the Banach space of all abstract continuous functions $\varphi(t)$ defined on $[0, T]$ with values in $H$ equipped with the norm

$$
\|\varphi\|_{C([0, T], H)}=\max _{0 \leq t \leq T}\|\varphi(t)\|_{H}
$$

Moreover, let the Sobolev space $W_{2}^{2}[-\ell, \ell]$ be defined as the set of all functions $v(x)$ defined on $[-\ell, \ell]$ such that both $v(x)$ and $v^{\prime \prime}(x)$ are locally integrable in $L_{2}[-\ell, \ell]$, equipped with the norm

$$
\|v\|_{W_{2}^{2}[-\ell, \ell]}=\left(\int_{-\ell}^{\ell}|v(x)|^{2} d x\right)^{1 / 2}+\left(\int_{-\ell}^{\ell}\left|v^{\prime \prime}(x)\right|^{2} d x\right)^{1 / 2} .
$$

Theorem 1. Assume that $f(t, x)$ and $\zeta(t)$ are continuously differentiable functions. Then the SIP (1) has a unique solution $u \in C\left(L_{2}[-l, l]\right)$ and $p \in C[0, T]$, and for the solution of SIP (1) the following stability estimates hold

$$
\begin{gathered}
\left\|u_{t}\right\|_{C\left(L_{2}[-l, l]\right)}+\|u\|_{C\left(W_{2}^{2}[-l, l]\right)}+\|p\|_{C[0, T]} \leqslant M(q, \delta)\left[\|\varphi\|_{W_{2}^{2}[-l, l]}\right. \\
\left.+\|g(0, \cdot)\|_{L_{2}[-l, l]}+\left\|g_{t}\right\|_{C\left(L_{2}[-l, l]\right)}+\left\|\zeta_{t}\right\|_{C[0, T]}\right] .
\end{gathered}
$$

Theorem 2. Assume that $g(t, x)$ and $\zeta(t)$ are continuously differentiable functions and $\zeta_{t}(t)$ is satisfying a Hölder condition with the ; weight $t^{\alpha}$. Then the SIP $(1)$ has a unique solution $u \in C_{0}^{\alpha}\left([0, T], L_{2}[-l, l]\right)$ and $p \in C_{0}^{\alpha}[0, T]$. For the solution of SIP (1) the following coercive stability estimates hold:

$$
\begin{gathered}
\left\|u_{t}\right\|_{C_{0}^{\alpha}\left([0, T], L_{2}[-l, l]\right)}+\|u\|_{C_{0}^{\alpha}\left([0, T], W_{2}^{2}[-l, l]\right)}+\|p\|_{C_{0}^{\alpha}[0, T]} \leqslant M(q, \delta)\left[\|\varphi\|_{W_{2}^{2}[-l, l]}\right. \\
\left.+\frac{1}{\alpha(1-\alpha)}\|g\|_{C_{0}^{\alpha}\left([0, T], L_{2}[-l, l]\right)}+\left\|\zeta_{t}\right\|_{C_{0}^{\alpha}[0, T]}\right] .
\end{gathered}
$$

Proof. Denoted as

$$
u(t, x)=w(t, x)+\eta(t) q(x)
$$

where

$$
\eta(t)=\int_{0}^{t} p(s) d s, \quad \eta(0)=0
$$

and $w(t, x)$ is the solution of the following problem

$$
\left\{\begin{array}{l}
w_{t}(t, x)-\left(a(x) w_{x}(t, x)\right)_{x}+\delta w(t, x) \\
=g(t, x)+\eta(t)\left[\left(a(x) q_{x}(x)\right)_{x}-\delta q(x)\right] \\
x \in(-l, l), t \in(0, T), \\
w(0, x)=\varphi(x), x \in[-l, l] \\
w_{x}(t,-l)=w_{x}(t, l)=0, t \in[0, T] .
\end{array}\right.
$$


Applying the condition

$$
\int_{0}^{l} u(t, x) d x=\zeta(t)
$$

and formula (3), we can write

$$
\eta(t)=q\left(-\zeta(t)+\int_{0}^{l} w(t, x) d x\right),
$$

where

$$
q=\frac{1}{\int_{0}^{l} q(x) d x} .
$$

Applying formulas (4) and (6), we get

$$
p(t)=q\left(-\zeta^{\prime}(t)+\int_{0}^{l} w_{t}(t, x) d x\right) .
$$

Applying $\int_{0}^{l} q(x) d x \neq 0$, we get the estimate

$$
|p(t)| \leqslant K_{1}(q)\left[\left|\zeta_{t}(t)\right|+\|\left. w_{t}(t, \cdot)\right|_{L_{2}[-l, l]}\right]
$$

for each $t \in[0, T]$. From (7) and (8) follows it

$$
\begin{gathered}
\|p\|_{C([0, T])} \leq K_{1}(q)\left[\left\|\zeta_{t}\right\|_{C[0, T]}+\left\|w_{t}\right\|_{C\left([0, T], L_{2}[-l, l]\right)}\right], \\
\|p\|_{C_{0}^{\alpha}[0, T]} \leq K_{2}(q)\left[\left\|\zeta_{t}\right\|_{\left.C_{0}^{\alpha}[0, T]\right)}+\left\|w_{t}\right\|_{C_{0}^{\alpha}\left([0, T], L_{2}[-l, l]\right)}\right] .
\end{gathered}
$$

Applying (3), we get

and

$$
u_{t}(t, x)=w_{t}(t, x)+p(t) q(x)
$$

$$
\begin{gathered}
\left\|u_{t}\right\|_{C\left([0, T], L_{2}[-l, l]\right)} \leqslant\left\|w_{t}\right\|_{C\left([0, T], L_{2}[-l, l]\right)}+\|p\|_{C[0, T])}\|q\|_{\left.L_{2}[-l, l]\right)}, \\
\left\|u_{t}\right\|_{C_{0}^{\alpha}\left([0, T], L_{2}[-l, l]\right)} \leqslant\left\|w_{t}\right\|_{C_{0}^{\alpha}\left([0, T], L_{2}[-l, l]\right)}+\|p\|_{\left.C_{0}^{\alpha}[0, T]\right)}\|q\|_{\left.L_{2}[-l, l]\right)} .
\end{gathered}
$$

Therefore, the following theorems will complete the proof of Theorem 1 and 2.

Theorem 3. Under assumptions of Theorem 1 , in $C\left([0, T], L_{2}[-l, l]\right)$ the problem (5) has a unique solution and the following stability estimate is satisfied:

$$
\begin{aligned}
& \left\|w_{t}\right\|_{C\left([0, T], L_{2}[-l, l]\right)} \leqslant K_{2}(q, \delta)\left[\|\varphi\|_{W_{2}^{2}[-l, l]}+|\zeta(0)|\right. \\
& \left.+\|g(0, \cdot)\|_{L_{2}[-l, l]}+\left\|g_{t}\right\|_{C\left([0, T], L_{2}[-l, l]\right)}+\left\|\zeta_{t}\right\|_{C[0, T]}\right] .
\end{aligned}
$$

Theorem 4. Under assumptions of Theorem 2 , in $C_{0}^{\alpha}\left([0, T], L_{2}[-l, l]\right)$ the problem (5) has a unique solution and the following coercive stability estimate is satisfied:

$$
\begin{aligned}
& \left\|w_{t}\right\|_{C_{0}^{\alpha}\left([0, T], L_{2}[-l, l]\right)} \leqslant K_{2}(q, \delta)\left[\|\varphi\|_{W_{2}^{2}[-l, l]}\right. \\
& \left.+\frac{1}{\alpha(1-\alpha)}\|g\|_{C_{0}^{\alpha}\left([0, T], L_{2}[-l, l]\right)}+\left\|\zeta_{t}\right\|_{C_{0}^{\alpha}[0, T]}\right] .
\end{aligned}
$$

Proof. Problem (5) can be written in the following abstract form

$$
\left\{\begin{array}{l}
w^{\prime}(t)+A w(t)=-\eta(t) A q+g(t), 0<t<T, \\
w(0)=\varphi
\end{array}\right.
$$

in a Hilbert space $H=L_{2}[-\ell, \ell]$ with the space operator $A=A^{x}$ defined by the formula $(2)$. Here $g(t)=g(t, x)$ is given abstract function, $w(t)=w(t, x)$ is unknown function, and $q=q(x)$ is the unknown element of $L_{2}[-\ell, \ell]$. The proofs of Theorems 3 and 4 are based on estimates (8), (9) and (10), theorems on stability and coercive stability of the abstract problem (11) [9], the integral inequality and the self-adjointness and positive definiteness of the space operator $A^{x}$ defined by formula (2) [15]. 
Stability and coercive stability of DS

Let $\alpha \in(0,1)$ be a given number and $\left.C_{\tau}^{\alpha}(H)=C_{0}^{\alpha}\left([0, T]_{\tau}, H\right]\right), C_{\tau}(H)=C\left([0, T]_{\tau}, H\right)$ be Banach spaces of all $H$-valued mesh functions $w_{\tau}=\left\{w_{k}\right\}_{k=0}^{N}$ defined on

$$
[0, T]_{\tau}=\left\{t_{k}=k \tau, 0 \leqslant k \leqslant N, N \tau=T\right\}
$$

with the corresponding norms

$$
\begin{gathered}
\left\|w_{\tau}\right\|_{C_{\tau}(H)}=\max _{0 \leq k \leq N}\left\|w_{k}\right\|_{H}, \\
\left\|w_{\tau}\right\|_{C_{\tau}^{\alpha}(H)}=\sup _{1 \leq k<k+n \leq N}(N-n)^{-\alpha}(k)^{\alpha}\left\|w_{k+n}-w_{k}\right\|_{H}+\left\|w_{\tau}\right\|_{C_{\tau}(H)} .
\end{gathered}
$$

Moreover, let $L_{2 h}=L_{2}[-l, l]_{h}$ and $W_{2 h}^{2}=W_{2}^{2}[-l, l]_{h}$ be normed spaces of all mesh functions $\gamma^{h}(x)=\left\{\gamma_{n}\right\}_{n=-M}^{M}$ defined on

$$
[-l, l]_{h}=\left\{x_{n}=n h,-M \leqslant n \leqslant M, M h=l\right\}
$$

equipped with norms

$$
\left\|\gamma^{h}\right\|_{L_{2 h}}=\left(\sum_{x \in[-l, l]_{h}}\left|\gamma^{h}(x)\right|^{2} h\right)^{1 / 2}
$$

and

$$
\left\|\gamma^{h}\right\|_{W_{2 h}^{2}}=\left\|\gamma^{h}\right\|_{L_{2 h}}+\left(\sum_{x \in[-l, l]_{h}}\left|\left(\gamma^{h}\right)_{x \bar{x}, j}\right|^{2} h\right)^{1 / 2},
$$

respectively. Moreover, we introduce the difference operator $A_{h}^{x}$ defined by the formula

$$
A_{h}^{x} u^{h}(x)=\left\{-\left(a(x) u_{\bar{x}}(x)\right)_{x, r}-\beta\left(a(-x) u_{\bar{x}}(-x)\right)_{x, r}+\delta u_{r}\right\}_{-M+1}^{M-1},
$$

acting in the space of mesh functions $u^{h}(x)=\left\{u_{n}\right\}_{n=-M}^{M}$ defined on $[-l, l]_{h}$ satisfying the conditions $u_{M}-u_{M-1}=u_{-M}-u_{-M+1}=0$. For the numerical solution $\left\{u_{k}^{h}(x)\right\}_{k=0}^{N}$ of SIP (1) we present DS of the first order of approximation

$$
\left\{\begin{array}{l}
\frac{u_{n}^{k}-u_{n}^{k-1}}{\tau}-\frac{1}{h}\left(a_{n+1} \frac{u_{n+1}^{k}-u_{n}^{k}}{h}-a_{n} \frac{u_{n}^{k}-u_{n-1}^{k}}{h}\right)-\frac{\beta}{h}\left(a_{-n+1} \frac{u_{-n+1}^{k}-u_{-n}^{k}}{h}-a_{-n} \frac{u_{-n}^{k}-u_{-n-1}^{k}}{h}\right) \\
+\delta u_{n}^{k}=p_{k} q_{n}+g_{n}^{k}, g_{n}^{k}=g\left(t_{k}, x_{n}\right), t_{k} \in[0, T]_{\tau}, x_{n} \in[-l, l]_{h}, \quad k \in \overline{1, N}, \quad n \in \overline{1, M-1} \\
u_{n}^{0}=\varphi_{n}, \varphi_{n}=\varphi\left(x_{n}\right), n \in \overline{0, M}, \\
u_{M}^{k}-u_{M-1}^{k}=u_{-M+1}^{k}-u_{-M}^{k}=0, \sum_{i=1}^{M} u_{i}^{k} h=\zeta_{k}, \zeta_{k}=\zeta\left(t_{k}\right), \quad k \in \overline{0, N}
\end{array}\right.
$$

Here it is assumed that $q_{M}-q_{M-1}=q_{-M}-q_{-M+1}=0$, and $\sum_{m=1}^{M} q_{m} h \neq 0$. Let us give the following results on the stability of DS (13).

Theorem 5. For the solution of DS (13), the stability estimate

$$
\begin{gathered}
\left\|\left\{\frac{1}{\tau}\left(u_{k}^{h}-u_{k-1}^{h}\right)\right\}_{k=1}^{N}\right\|_{C_{\tau}\left(L_{2 h}\right)}+\left\|\left\{u_{k}^{h}\right\}_{k=1}^{N}\right\|_{C_{\tau}\left(W_{2 h}^{2}\right)}+\left\|\left\{p_{k}\right\}_{k=1}^{N}\right\|_{C[0, T]_{\tau}} \\
\leqslant K(q)\left[\left\|\varphi^{h}\right\|_{W_{2 h}^{2}}+\left\|g_{1}^{h}\right\|_{L_{2 h}}+\left|\zeta_{0}\right|\right. \\
\left.+\left\|\left\{\frac{1}{\tau}\left(g_{k}^{h}-g_{k-1}^{h}\right)\right\}_{k=2}^{N}\right\|_{C_{\tau}\left(L_{2 h}\right)}+\left\|\left\{\frac{1}{\tau}\left(\zeta_{k}-\zeta_{k-1}\right)\right\}_{k=1}^{N}\right\|_{C[0, T]_{\tau}}\right],
\end{gathered}
$$


and coercive stability estimate

$$
\begin{gathered}
\left\|\left\{\frac{1}{\tau}\left(u_{k}^{h}-u_{k-1}^{h}\right)\right\}_{k=1}^{N}\right\|_{C_{\tau}^{\alpha}\left(L_{2 h}\right)}+\left\|\left\{u_{k}^{h}\right\}_{k=1}^{N}\right\|_{C_{\tau}^{\alpha}\left(W_{2 h}^{2}\right)}+\left\|\left\{p_{k}\right\}_{k=1}^{N}\right\|_{C_{0}^{\alpha}[0, T]_{\tau}} \\
\leqslant K(q)\left[\left\|\varphi^{h}\right\|_{W_{2 h}^{2}}\right. \\
\left.+\frac{1}{\alpha(1-\alpha)}\left\|\left\{g_{k}^{h}\right\}_{k=1}^{N}\right\|_{C_{\tau}^{\alpha}\left(L_{2 h}\right)}+\left\|\left\{\frac{1}{\tau}\left(\zeta_{k}-\zeta_{k-1}\right)\right\}_{k=1}^{N}\right\|_{C_{0}^{\alpha}[0, T]_{\tau}}\right]
\end{gathered}
$$

hold.

Proof. We will use

$$
u_{n}^{k}=w_{n}^{k}+\eta_{k} q_{n}
$$

where

$$
q_{n}=q\left(x_{n}\right), \eta_{k}=\sum_{m=1}^{k} p_{m} \tau
$$

It is easy to use $\left\{w_{k}^{h}(x)\right\}_{k=0}^{N}$ as the solution of the following DS

$$
\begin{aligned}
& \frac{w_{n}^{k}-w_{n}^{k-1}}{\tau}-\left[\frac{1}{h}\left(a_{n+1} \frac{w_{n+1}^{k}-w_{n}^{k}}{h}-a_{n} \frac{w_{n}^{k}-w_{n-1}^{k}}{h}\right)\right. \\
& -\frac{\beta}{h}\left(a_{-n+1} \frac{w_{-n+1}^{k}-w_{-n}^{k}}{h}-a_{-n} \frac{w_{-n}^{k}-w_{-n-1}^{k}}{h}\right)+\delta w_{n}^{k} \\
& =-\left[-\frac{1}{h}\left(q_{n+1} \frac{w_{n+1}^{k}-w_{n}^{k}}{h}-q_{n} \frac{w_{n}^{k}-w_{n-1}^{k}}{h}\right)\right. \\
& \left.-\frac{\beta}{h}\left(q_{-n+1} \frac{w_{-n+1}^{k}-w_{-n}^{k}}{h}-q_{-n} \frac{w_{-n}^{k}-w_{-n-1}^{k}}{h}\right)+\delta q_{n}^{k} \eta_{k}\right]+g_{n}^{k}, \\
& k \in \overline{1, N}, n \in \overline{1, M-1}, \\
& w_{n}^{0}=\varphi_{n}, n \in \overline{0, M}, \\
& w_{M}^{k}-w_{M-1}^{k}=w_{-M+1}^{k}-w_{-M}^{k}=0, k \in k \in \overline{0, N} .
\end{aligned}
$$

Now we estimate $\left|p_{k}\right|$. Using the condition $\sum_{m=1}^{M} u_{m}^{k} h=\zeta_{k}$ and (14), we obtain

$$
\eta_{k}=b_{1}\left(\zeta_{k}-\sum_{m=1}^{M} w_{m}^{k} h\right)
$$

where

$$
b_{1}=\frac{1}{\sum_{m=1}^{M} q_{m} h} .
$$

Then,

$$
p_{k}=\frac{b_{1}}{\tau}\left(\zeta_{k}-\zeta_{k-1}-\sum_{m=1}^{M}\left(w_{m}^{k}-w_{m}^{k-1}\right) h\right) .
$$

Applying the Cauchy-Schwartz inequality, we get

$$
\begin{gathered}
\left|p_{k}\right| \leqslant\left|b_{1}\right|\left[\left|\frac{\zeta_{k}-\zeta_{k-1}}{\tau}\right|+\sum_{m=1}^{M}\left|\frac{w_{m}^{k}-w_{m}^{k-1}}{\tau}\right| h\right] \\
\leqslant K(b)\left[\left|\frac{\zeta_{k}-\zeta_{k-1}}{\tau}\right|+\left\|\frac{w_{k}^{h}-w_{k-1}^{h}}{\tau}\right\|_{L_{2 h}}\right]
\end{gathered}
$$

for every $1 \leqslant k \leqslant N$, and

$$
\left\|\left\{p_{k}\right\}_{k=1}^{N}\right\|_{C[0, T]_{\tau}}
$$




$$
\leqslant K(b)\left[\left\|\left\{\frac{\zeta_{k}-\zeta_{k-1}}{\tau}\right\}_{k=1}^{N}\right\|_{C[0, T]_{\tau}}+\left\|\left\{\frac{w_{k}^{h}-w_{k-1}^{h}}{\tau}\right\}_{k=1}^{N}\right\|_{C_{\tau}\left(L_{2 h}\right)}\right] .
$$

Moreover, using (16), we can write

$$
\leqslant K(b)\left[\left\|\left\{\frac{\zeta_{k}-\zeta_{k-1}}{\tau}\right\}_{k=1}^{N}\right\|_{C_{0}^{\alpha}[0, T]_{\tau}}+\left\|\left\{\frac{w_{k}^{h}-w_{k-1}^{h}}{\tau}\right\}_{k=1}^{N}\right\|_{C_{\tau}^{\alpha}\left[L_{2 h}\right)}^{N} \| .\right.
$$

Applying (14), we obtain

From that it follows

$$
\frac{u_{n}^{k}-u_{n}^{k-1}}{\tau}=\frac{w_{n}^{k}-w_{n}^{k-1}}{\tau}+p_{k} q_{n} .
$$

$$
\begin{gathered}
\left\|\left\{\frac{1}{\tau}\left(u_{k}^{h}-u_{k-1}^{h}\right)\right\}_{k=1}^{N}\right\|_{C_{\tau}\left(L_{2 h}\right)} \\
\leqslant\left\|\left\{\frac{1}{\tau}\left(w_{k}^{h}-w_{k-1}^{h}\right)\right\}_{k=1}^{N}\right\|_{C_{\tau}\left(L_{2 h}\right)}+\left\|\left\{p_{k}\right\}_{k=1}^{N}\right\|_{C[0, T]_{\tau}}\left\|q^{h}\right\|_{L_{2 h}}
\end{gathered}
$$

and

$$
\begin{gathered}
\left\|\left\{\frac{1}{\tau}\left(u_{k}^{h}-u_{k-1}^{h}\right)\right\}_{k=1}^{N}\right\|_{C_{\tau}^{\alpha}\left(L_{2 h}\right)} \\
\leqslant\left\|\left\{\frac{1}{\tau}\left(w_{k}^{h}-w_{k-1}^{h}\right)\right\}_{k=1}^{N}\right\|_{C_{\tau}^{\alpha}\left(L_{2 h}\right)}+\left\|\left\{p_{k}\right\}_{k=1}^{N}\right\|_{C_{0}^{\alpha}[0, T]_{\tau}}\left\|q^{h}\right\|_{L_{2 h}} .
\end{gathered}
$$

Therefore, the following theorem will complete the proof of Theorem 5 .

Theorem 6. For the solution of DS (15), the stability estimate

$$
\begin{gathered}
\left\|\left\{\frac{1}{\tau}\left(w_{k}^{h}-w_{k-1}^{h}\right)\right\}_{k=1}^{N}\right\|_{C_{\tau}\left(L_{2 h}\right)} \leqslant K_{3}(a)\left[\left\|\varphi^{h}\right\|_{W_{2 h}^{2}}+\left\|g_{1}^{h}\right\|_{L_{2 h}}+\left|\zeta_{0}\right|\right. \\
\left.+\left\|\left\{\frac{1}{\tau}\left(g_{k}^{h}-g_{k-1}^{h}\right)\right\}_{k=2}^{N}\right\|_{C_{\tau\left(L_{2 h}\right)}}+\left\|\left\{\frac{\zeta_{k}-\zeta_{k-1}}{\tau}\right\}_{k=1}^{N}\right\|_{C[0, T]_{\tau}}\right]
\end{gathered}
$$

and coercive stability estimate

$$
\begin{gathered}
\left\|\left\{\frac{1}{\tau}\left(w_{k}^{h}-w_{k-1}^{h}\right)\right\}_{k=1}^{N}\right\| \|_{C_{\tau}^{\alpha}\left(L_{2 h}\right)} \\
\leqslant K_{3}(q)\left[\left\|\varphi^{h}\right\|_{W_{2 h}^{2}}+\frac{1}{\alpha(1-\alpha)}\left\|\left\{g_{k}^{h}\right\}_{k=1}^{N}\right\|_{C_{\tau}^{\alpha}}+\left\|\left\{\frac{\zeta_{k}-\zeta_{k-1}}{\tau}\right\}_{k=1}^{N}\right\|_{C_{0}^{\alpha}[0, T]_{\tau}}\right]
\end{gathered}
$$

hold.

Proof. Problem (15) can be written in the following abstract form

$$
\left\{\begin{array}{l}
\frac{w_{k}^{h}-w_{k-1}^{h}}{\tau}+A^{h} w_{k}^{h}=g_{k}^{h}-A^{h} q^{h} \eta_{k}, \\
t_{k}=k \tau, 1 \leqslant k \leqslant N, w_{0}^{h}=\varphi^{h}
\end{array}\right.
$$

in a Hilbert space $H=L_{2 h}$ with the space operator $A^{h}=A_{h}^{x}$ defined by the formula (12). Here, $g_{k}^{h}=g_{k}^{h}(x)$ is given abstract mesh function, $w_{k}^{h}=w_{k}^{h}(x)$ is unknown mesh function and $q^{h}=q^{h}(x)$ is the unknown element of $L_{2 h}$. The proof of Theorem 6 is based on estimates (17), (18) and (19), theorems on stability and coercive stability of the abstract problem (20) (see [9]), difference analogy of integral inequalities, and the self-adjointness and positive definiteness of the difference operator $A_{h}^{x}$ defined by the formula (12) [15]. 


\section{Numerical experiment}

In this section a numerical computation to approximate solution of a time dependent source identification problem with involution and Neumann conditions is considered to support the theoretical results. We use the first order of accuracy difference schemes. The error analysis is given.

We consider

$$
\left\{\begin{array}{l}
u_{t}(t, x)-u_{x x}(t, x)-\frac{1}{2} u_{x x}(t,-x)+u(t, x) \\
=p(t)(1+\cos x)+\left(\frac{\cos x}{2}-1\right) e^{-t}, \quad x \in(-\pi, \pi), t \in(0, \pi), \\
u(0, x)=1+\cos x, x \in[-\pi, \pi], \\
u_{x}(t,-\pi)=u_{x}(t, \pi)=0, t \in[0, \pi], \\
\int_{0}^{\pi} u(t, s) d s=\pi e^{-t}, t \in[0, \pi]
\end{array}\right.
$$

for parabolic equation with involution and Neumann condition. The integral condition is given as an overdetermined condition. The exact solution of this problem is

$$
\begin{aligned}
u(t, x) & =(1+\cos x) e^{-t},-\pi \leq x \leq \pi, 0 \leq t \leq \pi \\
p(t) & =e^{-t}, t \in[0, \pi]
\end{aligned}
$$

Here we denote the set $[0, \pi]_{\tau} \times[-\pi, \pi]_{h}$ of all grid points

$$
\begin{gathered}
{[0, \pi]_{\tau} \times[-\pi, \pi]_{h}=\left\{\left(t_{k}, x_{n}\right): t_{k}=k \tau, 0 \leq k \leq N\right.} \\
\left.N \tau=\pi, x_{n}=n h,-M \leq n \leq M, M h=\pi\right\}
\end{gathered}
$$

For obtaining the solution to problem (21) we apply the substitution

$$
u(t, x)=w(t, x)+\eta(t)(1+\cos x),
$$

where

$$
\eta(t)=\int_{0}^{t} p(s) d s, \eta(0)=0 .
$$

One can show that after the substitution, problem (21) turns to

$$
\left\{\begin{array}{l}
w_{t}(t, x)-w_{x x}(t, x)-\frac{1}{2} w_{x x}(t,-x)+w(t, x) \\
=-\left(\frac{5 \cos x}{2}+1\right) \eta(t)+\left(\frac{\cos x}{2}-1\right) e^{-t}, x \in(-\pi, \pi), t \in(0, \pi), \\
w(0, x)=1+\cos x, x \in[-\pi, \pi] \\
w_{x}(t,-\pi)=w_{x}(t, \pi)=0, t \in[0, \pi] .
\end{array}\right.
$$

Moreover, using the overdetermined condition we can write

$$
\int_{0}^{\pi} u(t, s) d s=\int_{0}^{\pi} w(t, s) d s+\eta(t) \int_{0}^{\pi}(1+\cos s) d s=\pi e^{-t}
$$

and

$$
\eta(t)=\frac{\pi e^{-t}-\int_{0}^{\pi} w(t, s) d s}{\pi} .
$$

For the numerical solution of (22), we present the first order of accuracy difference scheme

$$
\left\{\begin{array}{l}
\tau^{-1}\left(w_{n}^{k}-w_{n}^{k-1}\right)-h^{-2}\left(w_{n+1}^{k}-2 w_{n}^{k}+w_{n-1}^{k}\right) \\
-\frac{1}{2} h^{-2}\left(w_{-n+1}^{k}-2 w_{-n}^{k}+w_{-n-1}^{k}\right)+w_{n}^{k} \\
-\frac{1}{\pi}\left(\frac{5 \cos x_{n}}{2}+1\right) \sum_{n=0}^{M-1} w_{n}^{k} h \\
=-\left(2+2 \cos x_{n}\right) e^{-t_{k}}, \\
1 \leq k \leq N,-M+1 \leq n \leq M-1, \\
w_{n}^{0}=1+\cos x_{n},-M \leq n \leq M, \\
w_{-M+1}^{k}-w_{-M}^{k}=w_{M}^{k}-w_{M-1}^{k}=0,0 \leq k \leq N .
\end{array}\right.
$$


For obtaining the solution of difference scheme (23), we rewrite it in the matrix form

$$
A W^{k}+B W^{k-1}=R \varphi^{k}, \quad 1 \leq k \leq N, W^{0}=\varphi,
$$

where

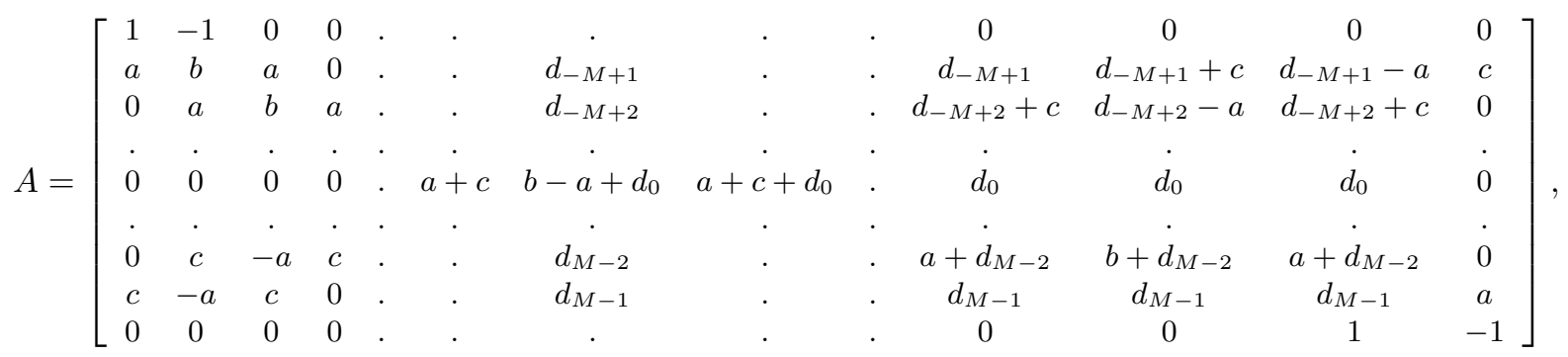

$$
\begin{aligned}
& B=\left[\begin{array}{cccccccc}
0 & 0 & 0 & 0 & . & 0 & 0 & 0 \\
0 & e & 0 & 0 & . & 0 & 0 & 0 \\
0 & 0 & e & 0 & . & 0 & 0 & 0 \\
. & . & . & . & . & . & . & . \\
0 & 0 & 0 & 0 & . & e & 0 & 0 \\
0 & 0 & 0 & 0 & . & 0 & e & 0 \\
0 & 0 & 0 & 0 & . & 0 & 0 & 0
\end{array}\right]
\end{aligned}
$$

and

$$
\begin{gathered}
a=-\frac{1}{h^{2}}, b=\frac{1}{\tau}+\frac{2}{h^{2}}+1, c=-\frac{1}{2 h^{2}}, e=\frac{1}{\tau}, \\
d_{i}=-\frac{h}{\pi}\left(\frac{5 \cos x_{i}}{2}+1\right), i=-M+1,-M+2, \ldots M-1, \\
W^{s}=\left[\begin{array}{l}
W_{-M}^{s} \\
\vdots \\
W_{M}^{s}
\end{array}\right] \text { for } s=k, k-1, \\
R=\left[\begin{array}{llll}
1 & 0 & . & 0 \\
0 & 1 & \cdot & 0 \\
\cdot & \cdot & \cdot & \cdot \\
0 & 0 & \cdot & 1
\end{array}\right], \varphi^{k}=\left[\begin{array}{l}
0 \\
\varphi_{-M+1}^{k} \\
\vdots \\
\varphi_{M-1}^{k} \\
0
\end{array}\right] .
\end{gathered}
$$

So, we have a first order difference equation with respect to $k$ with matrix coefficients. From (24) it follows that

$$
W^{k}=-A^{-1} B W^{k-1}+A^{-1} R \varphi^{k} \quad k=1, \cdots, N .
$$

In the second step, using the formulas

$$
\begin{gathered}
u_{n}^{k}=w_{n}^{k}+\eta_{k}\left(1+\cos x_{n}\right), 0 \leq k \leq N,-M \leq n \leq M, \\
\eta_{k}=\frac{\pi e^{-t_{k}}-\sum_{n=0}^{M-1} w_{n}^{k} h}{\pi}, 1 \leq k \leq N, \eta_{0}=0, \\
p_{k}=\frac{\eta_{k}-\eta_{k-1}}{\tau}, 1 \leq k \leq N,
\end{gathered}
$$

we can find the approximate solutions for $u(t, x)$ and $p(t)$.

We compute the error between the exact solution and numerical solution by

$$
\left\{\begin{aligned}
\left\|E_{u}\right\|_{\infty} & =\max _{0 \leq k \leq N,-M \leq n \leq M}\left|u\left(t_{k}, x_{n}\right)-u_{n}^{k}\right|, \\
\left\|E_{\eta}\right\|_{\infty} & =\max _{1<k<N}\left|\eta\left(t_{k}\right)-\eta_{k}\right|, \\
\left\|E_{p}\right\|_{\infty} & =\max _{1<k<N}\left|p\left(t_{k}\right)-p_{k}\right|,
\end{aligned}\right.
$$


where $u(t, x), p(t), \eta(t)$ represent the exact solutions, $u_{n}^{k}$ represents the numerical solution at $\left(t_{k}, x_{n}\right)$, and $p_{k}$ and $\eta_{k}$ represent the numerical solutions at $t_{k}$. The numerical results are given in Table 1.

\begin{tabular}{|c|c|c|c|}
\hline Errors & $\left\|E_{u}\right\|_{\infty}$ & $\left\|E_{\eta}\right\|_{\infty}$ & $\left\|E_{p}\right\|_{\infty}$ \\
\hline$N=M=30$ & $6.6666 \cdot 10^{-2}$ & $7.3894 \cdot 10^{-2}$ & $1.1917 \cdot 10^{-1}$ \\
\hline$N=M=60$ & $3.3333 \cdot 10^{-2}$ & $3.6655 \cdot 10^{-2}$ & $6.6532 \cdot 10^{-2}$ \\
\hline$N=M=120$ & $1.6667 \cdot 10^{-2}$ & $1.8262 \cdot 10^{-2}$ & $3.5167 \cdot 10^{-2}$ \\
\hline$N=M=240$ & $8.3333 \cdot 10^{-3}$ & $9.1165 \cdot 10^{-3}$ & $1.8081 \cdot 10^{-2}$ \\
\hline
\end{tabular}

\section{Conclusion}

In this paper we considered a time dependent source of identification problem for parabolic equation with involution and Neumann condition. The theoretical considerations that prove well-posedness theorem on the differential equation of the source identification parabolic problem and stability estimates for the difference scheme of the source identification parabolic problem were given. To support the theoretical results by a numerical experiment we constructed a stable difference scheme for the approximate solution of the problem. Obtained results given in Table 1 support the theoretical results.

\section{Acknowledgements}

We would like to thank the following institutions for their support. The publication has been prepared with the support of the "RUDN University Program 5-100". This research has been funded by the Science Committee of the Ministry of Education and Science of the Republic of Kazakhstan (Grant No. AP08855352).

\section{References}

1 Choulli M. Generic well-posedness of a linear inverse parabolic problem with respect to diffusion parameters / M. Choulli, M. Yamamoto // Journal of Inverse and III-Posed Problems. - 1999. - 7. - No.3. - P. 241254.

2 Ashyralyev A. On source identification problem for a delay parabolic equation / A. Ashyralyev, D. Agirseven // Nonlinear Analysis: Modelling and Control. - 2014. - 19. - No.3. - P. 335-349.

3 Ashyralyev A. On the problem of determining the parameter of an elliptic equation in a Banach space/ A. Ashyralyev, C. Ashyralyyev // Nonlinear Analysis: Modelling and Control. - 2014. — 19. - No. 3. P. 350-366.

4 Erdogan A.S. On the second order implicit difference schemes for a right hand side identification problem / A.S. Erdogan, A. Ashyralyev // Appl. Math. Comput. - 2014. - 226. - P. 212-228.

5 Ashyralyev A. On the determination of the right-hand side in a parabolic equation / A. Ashyralyev, A.S. Erdogan, O. Demirdag // Applied Numerical Mathematics. - 2012. - 62. - No. 11. - P. 16721683.

6 Ashyralyyev C. High order approximation of the inverse elliptic problem with Dirichlet-Neumann conditions / C. Ashyralyyev // Filomat. - 2014. - 28. - No. 5. - P. 947-962.

7 Blasio G. Di. Identification problems for parabolic delay differential equations with measurement on the boundary / G. Di. Blasio, A. Lorenzi // Journal of Inverse and Ill-Posed Problems. — 2007. — 15. No. 7. - P. 709-734.

8 Jator S. Block unification scheme for elliptic, telegraph, and Sine-Gordon partial differential equations / S. Jator // American Journal of Computational Mathematics. - 2015. - 5. - No. 2. — P. 175-185.

9 Ashyralyev A. New Difference Schemes for Partial Differential Equations / A. Ashyralyev, P.E. Sobolevskii // Birkhäuser Verlag, Basel, Boston, Berlin. - 2004.

10 Ashyralyev A. On source identification problem for a hyperbolic-parabolic equation / A. Ashyralyev, M.A. Ashyralyyeva // Contemporary Analysis and Applied Mathematics. - 2015. - 3. - No. 1 . P. 88-103. 
11 Ashyralyyeva M.A. Stable difference scheme for the solution of the source identification problem for hyperbolic-parabolic equations / M.A. Ashyralyyeva, A. Ashyralyyev // AIP Conference Proceedings. 2015. - 1676. Article Number: 020024.

12 Ashyralyyeva M.A. On the numerical solution of identification hyperbolic-parabolic problems with the Neumann boundary condition / M.A. Ashyralyyeva, M. Ashyraliyev // Bulletin of the Karaganda University-Mathematics. - 2018. - 91. - No.3. - P. 69-74.

13 Ashyralyyeva M.A. Numerical solutions of source identification problem for hyperbolic-parabolic equations / M.A. Ashyralyyeva, M. Ashyraliyev // AIP Conference Proceedings. - 2018. - 1997. Article Number: 020048.

14 Ashyralyev A. Well-posedness of an elliptic equation with involution / A. Ashyralyev, A. Sarsenbi // Electron. J. Differential Equations. - 2015. - 2015. - 284. - P. 1-8.

15 Ashyralyev A. Well-Posedness of a parabolic equation with involution / A. Ashyralyev, A. Sarsenbi // Numerical Functional Analysis and Optimization. - 2017. - 38. - No.10. - P. 1295-1304.

16 Ashyralyev A. Stability of a hyperbolic equation with the involution, in: Functional Analysis in Interdisciplinary Applications / A. Ashyralyev, A. Sarsenbi // Vol. 216 of Springer Proceedings in Mathematics \& Statistics Book Series. - 2016. - P. 204-212.

17 Cabada A. Differential Equations with Involutions / A. Cabada, F. Tojo. Atlantis Press.

\author{
А. Ашыралыев ${ }^{1-3}$, А.С. Ердоган ${ }^{4}$ \\ ${ }^{1}$ Таяу Шывыс университеті, Никосия, Түркия; \\ ${ }^{2}$ Ресей халықтар достыъы университеті, Мәскеу, Ресей; \\ ${ }^{3}$ Математика және математикалық, модельдеу институты, Алматы, Қазақстан; \\ ${ }^{4}$ Палм-Бич мемлекеттік колледжі, Флорида, АҚШ
}

\title{
Инволюциямен және Дирихле шартымен сәйкестендірудің параболалық мәселесі туралы ескерту
}

Инволюция және Дирихле шарты бар параболалық теңдеу үшін дереккөзді анықтаудың кеңістіктік есептері зерттелді. Параболалық дифференциалдық теңдеу үшін дереккөзді анықтау есебінің дұрыстығы теоремасы анықталды. Бұл есептің жуық шешімін табу үшін тұрақты айырымдық схема берілген. Сонымен қатар, дереккөзді сәйкестендірудің параболалық есебінің айырымдық схемасының тұрақтылығының бағалаулары ұсынылған. Сандық нәтижелер келтірілген.

Kiлm сөздер: корректілік, эллипстік теңдеулер, коэрцитивті тұрақтылық, дереккөзді идентификациялау, дәл бағалаулар, шеттік есеп.

\author{
А. Ашыралыев ${ }^{1-3}$, А.С. Ердоган ${ }^{4}$ \\ ${ }^{1}$ Ближневосточный университет, Никосия, Туриия; \\ ${ }^{2}$ Российский университет дружбы народов, Москва, Россия; \\ ${ }^{3}$ Институт математики и математического моделирования, Алматы, Казахстан; \\ ${ }^{4}$ Государственный колледж Палм-Бич, Флорида, США
}

\section{Замечание о параболической проблеме идентификации с инволюцией и условием Дирихле}

\begin{abstract}
Исследованы пространственные задачи идентификации источника для параболического уравнения с инволюцией и условием Дирихле. Установлена теорема корректности задачи идентификации источника для параболического дифференциального уравнения. Представлена устойчивая разностная схема для приближенного решения этой задачи. Кроме того, даны оценки устойчивости разностной схемы параболической задачи идентификации источника. Приведены численные результаты.
\end{abstract}

Ключевые слова: корректность, эллиптические уравнения, положительность, коэрцитивная устойчивость, идентификация источника, точные оценки, краевая задача. 


\section{References}

1 Choulli, M., \& Yamamoto, M. (1999). Generic well-posedness of a linear inverse parabolic problem with respect to diffusion parameters. Journal of Inverse and III-Posed Problems, 7(3), 241-254.

2 Ashyralyev, A., \& Agirseven, D. (2014). On source identification problem for a delay parabolic equation. Nonlinear Analysis: Modelling and Control, 19(3), 335-349.

3 Ashyralyev, A., \& Ashyralyyev, C. (2014). On the problem of determining the parameter of an elliptic equation in a Banach space. Nonlinear Analysis: Modelling and Control, 19(3), 350-366.

4 Erdogan, A.S., \& Ashyralyev, A. (2014). On the second order implicit difference schemes for a right hand side identification problem. Appl. Math. Comput., 226, 212-228.

5 Ashyralyev, A., Erdogan, A.S., \& Demirdag, O. (2012). On the determination of the right-hand side in a parabolic equation. Applied Numerical Mathematics, 62(11), 1672-1683.

6 Ashyralyyev, C. (2014). High order approximation of the inverse elliptic problem with Dirichlet-Neumann conditions. Filomat, 28(5), 947-962.

7 Blasio, G. Di., \& Lorenzi, A. (2007). Identification problems for parabolic delay differential equations with measurement on the boundary. Journal of Inverse and Ill-Posed Problems, 15 (7), 709-734.

8 Jator, S. (2015). Block unification scheme for elliptic, telegraph, and Sine-Gordon partial differential equations. American Journal of Computational Mathematics, 5(2), 175-185.

9 Ashyralyev, A., \& Sobolevskii, P.E. New Difference Schemes for Partial Differential Equations. Birkhäuser Verlag, Basel, Boston, Berlin, 2004.

10 Ashyralyev, A., \& Ashyralyyeva, M.A. (2015). On source identification problem for a hyperbolic-parabolic equation. Contemporary Analysis and Applied Mathematics, 3(1), 88-103.

11 Ashyralyyeva, M.A., \& Ashyralyyev, A. (2015). Stable difference scheme for the solution of the source identification problem for hyperbolic-parabolic equations. AIP Conference Proceedings, 1676, Article Number: 020024.

12 Ashyralyyeva, M.A., \& Ashyraliyev, M. (2018). On the numerical solution of identification hyperbolicparabolic problems with the Neumann boundary condition. Bulletin of the Karaganda University-Mathematics, $91(3)$, 69-74.

13 Ashyralyyeva, M.A., \& Ashyraliyev, M. (2018). Numerical solutions of source identification problem for hyperbolic-parabolic equations. AIP Conference Proceedings, 1997. Article Number: 020048.

14 Ashyralyev, A., \& Sarsenbi, A. (2015). Well-posedness of an elliptic equation with involution. Electron. J. Differential Equations, 2015, 284, 1-8.

15 Ashyralyev, A., \& Sarsenbi, A. (2017). Well-Posedness of a parabolic equation with involution. Numerical Functional Analysis and Optimization, 38(10), 1295-1304.

16 Ashyralyev, A., \& Sarsenbi, A. (2016). Stability of a hyperbolic equation with the involution, in: Functional Analysis in Interdisciplinary Applications. Vol. 216 of Springer Proceedings in Mathematics \& Statistics Book Series, 204-212.

17 Cabada, A., \& Tojo, F. Differential Equations with Involutions. Atlantis Press, 2015. 